Available online at: http://ejournal-balitbang.kkp.go.id/index.php/iaj

\title{
COMPENSATORY GROWTH OF Oreochromis niloticus SELECTED STRAIN FROM BOGOR, WEST JAVA
}

\author{
Vitas Atmadi Prakoso*\# and Kurniawan*) \\ *) Institute for Freshwater Aquaculture Research and Fisheries Extension \\ *) Master of Science-Aquaculture Student, Flinders University-Australia
}

(Received 6 December 2016; Final revised 25 September 2017; Accepted 25 September 2017)

\begin{abstract}
Inefficient feed management strategy in aquaculture will increase the fish production cost. One of the most effective strategies to solve this problem is through a better understanding of the compensatory growth of cultured fish. 0 . niloticus BEST tilapia strain (total length: $7.23 \pm 0.11 \mathrm{~cm}$ mean \pm SD; Body weight: $7.04 \pm 0.08 \mathrm{~g}$ mean $\pm \mathrm{SD}$ ) were reared in aquariums at $26.3 \pm 1.4^{\circ} \mathrm{C}$ for 10 weeks. During the experiment, the control group was fed twice a day. The other two groups were deprived of food for one and two weeks and then fed twice a day during refeeding period. At the end of the experiment, the fish deprived for one week had a body weight, biomass and specific growth rate that were not significantly different from the control group. The body weight, biomass and specific growth rate of fish deprived for two weeks were significantly lower than the other groups. This study revealed that concentrations of ash and lower concentrations of protein and lipid on the deprived groups were higher compared to those without feed deprivation. Mortality of fish was lower than $9 \%$ and not significantly different among the treatments. Fish aggressive behavior was the main reason for injuries and death. Given the results, BEST tilapia strain was only able to reach complete growth compensation not longer than one week deprivation period. The results of the present study could be applied as basic information for further research on feeding management of BEST tilapia strain.
\end{abstract}

\section{KEYWORDS: Oreochromis niloticus; compensatory growth; feed deprivation; mortality}

\section{INTRODUCTION}

An increase in feed prices often has a profound impact on aquaculture. Feed accounts for over 70 percent of the production cost. Fish farmers must have detailed knowledge of nutritional requirements $\&$ optimal feeding practices to anticipate higher feed price. Inefficient feeding management will lead to higher fish production cost. One of the effective strategies to reduce production cost in aquaculture is by understanding the compensatory growth of cultured fish species (Jobling, 2010). Compensatory growth is defined as the phase of exceptionally rapid growth, following a period of nutritional deficiencies (Hayward et al., 1997; Ali et al., 2001).

\footnotetext{
\# Correspondence: Institute for Freshwater Aquaculture Research and Fisheries Extension. Jl. Sempur No.1, Bogor 16154, West Java, Indonesia.

Phone: + 622518313200

E-mail: vitas.atmadi@gmail.com
}

Previous studies on the compensatory growth of fish have been successfully conducted on both cold water and warm water fish species (Wang et al., 2000; Stefansson et al., 2009; Jiwyam, 2010; Peres et al., 2011; Urbinati et al., 2014). Compensatory growth response has been reported in many fish species following feed deprivation (Xie et al., 2001; Wang et al., 2005; Cho et al., 2006; Ribeiro \& Tsuzuki, 2010; Mohanta et al., 2016).

Nile tilapia Oreochromis niloticus is a warm water, euryhaline, omnivorous fish species. The species is globally the most popular and produced in high quantity. This species has become one of the most common culture species in Indonesia whose production continues to grow. One of Nile tilapia strains available in Indonesia is BEST (Bogor Enhanced Strain Tilapia) strain. BEST tilapia strain is a genetically selected strain with the excellent trait in growth performance. This strain was produced through a selective breeding conducted by a research team from the Institute of Freshwater Aquaculture Research and 
Development, Bogor (Gustiano, 2009). BEST tilapia strain has several advantages over its predecessor (Red NIFI, Nirwana, and GESIT). For examples, in general: it has better growth performance, disease resistance, and environmental tolerance. Specifically, BEST tilapia strain is $140 \%$ disease resistance to Streptococcus compared to other existing tilapia varieties in Indonesia (Gustiano, 2009).

Hayward et al. (1997) stated that the compensatory growth can be used as a management tool to improve growth, feed efficiency, and also reduce the cost of feed. According to Hitchcock (2013), using compensatory growth, farmers can reduce costs by using less amount of feed than usual without reducing the yields. However, the information of compensatory growth specifically on BEST tilapia strain has not yet available. Therefore, the objective of the present study was to investigate whether compensatory growth occurs in BEST tilapia strain in order to improve its aquaculture management.

\section{MATERIALS AND METHODS}

The experiment was carried out from January to February 2016 at the Institute for Freshwater Aquaculture Research and Fisheries Extension, Bogor. This study used BEST tilapia, Oreochromis niloticus, strain from Bogor as the experimental fish.

A total of 180 fish were stocked in nine aquariums (50 cmx $40 \mathrm{~cm} \times 40 \mathrm{~cm}$; water level: $30 \mathrm{~cm}$ ) with the density of 20 fish per aquaria. The fish were fed twice a day using a commercial pellet feed containing $31 \%$ crude protein and $3.0 \%$ crude lipid (Hi-ProVite 781-1).

Initially, the fish (Mean total length: $7.23 \pm 0.11$ $\mathrm{cm}$; Mean body weight: $7.04 \pm 0.08 \mathrm{~g}$ ) were starved $24 \mathrm{~h}$ prior stocking into the aquariums with the stocking density of 20 fish per aquaria. A completely randomized design (CRD) was used in this experiment with three feeding regimes and three replications. Three fish from each treatment were sampled at the beginning and the end of the experiment for the analysis of initial body composition (moisture, protein, lipid, and ash).

The experiment lasted for 8 weeks and was divided into two periods, a feed deprivation period weeks one to two, and a refeeding period (weeks three to eight). Fish in the control treatment were fed to satiation twice a day throughout the eightweek period. The fish in the other three treatment groups were starved for one and two weeks during the feed deprivation period and then fed to satiation twice a day (07:00 and 15:00 h) during the refeeding period. The fish in each tank were batch-weighed at the end of the feed deprivation period and at the end of the experiment, following feed deprivation for $24 \mathrm{~h}$.

Chemical composition was analyzed from three fish which randomly caught from each tank so that 17 fish remained in each tank at the beginning of the refeeding period. At the end of the experiment, five fish from each tank were taken and pooled, autoclaved, homogenized, and dried to a constant weight at $105^{\circ} \mathrm{C}$ (Cui et al., 1997). Protein, lipid, and ash concentrations were determined for the fish samples from each tank using the methods described by Cui et al. (1997) to observe the effect of feed deprivation on protein, lipid, and ash concentrations of fish. During the experiment, water temperature was maintained at $26.3 \pm 1.4^{\circ} \mathrm{C}$ and photoperiod was conducted at 12:12-h light-dark (12L/12D). Specific growth rates of wet weight, protein, and lipid were calculated (Fu et al., 1998):

$$
\begin{gathered}
\text { Specific growth rate of wet weight= } \\
100\left(\ln W_{t}-\operatorname{InW}_{0}\right) t^{-1} \\
\text { Specific growth rate of protein= } \\
100\left(\operatorname{InW}_{\mathrm{Pt}}-\operatorname{InW}_{\mathrm{P} 0}\right) \mathrm{t}^{-1} \\
\text { Specific growth rate of lipid= } \\
100\left(\operatorname{InW}_{\mathrm{Lt}}-\operatorname{InW}_{\mathrm{L} 0}\right) \mathrm{t}^{-1}
\end{gathered}
$$

where $W_{t}$ is the final and $W_{0}$ the initial wet weight of the fish, $W_{p t}$ is final and $W_{p_{0}}$ the initial weight of the body protein, $W_{L t}$ is the final and $W_{L 0}$ the initial weight of body lipid, and $t$ is the duration of the experiment.

One-way analysis of variance (ANOVA) was performed to test the treatment effects, and Tukey's procedure was applied for multiple comparisons. $P$ value was used as an indication of significant differences. It was considered significant when $P<0.05$.

\section{RESULTS AND DISCUSSION}

Based on the weight gain comparison, the highest weight gain since refeeding period started was found on one-week deprived group. At the end of the experiment, the average weight of one week deprived group was not significantly different from those without deprivation ( $P>0.05$ ). On the contrary, the average of final weight from two weeks deprived group was significantly lower than other groups $(P<0.05)$ (Table 1).

After feed deprivation period, significant differences were found in the average fish biomass at different feed deprivation treatments. The final 
Table 1. Weight gain comparison of tilapia based on duration of feed deprivation

\begin{tabular}{cccc}
\hline $\begin{array}{c}\text { Duration of feed } \\
\text { deprivation (week) }\end{array}$ & $\begin{array}{c}\text { Initial weight } \\
\text { (g) }\end{array}$ & $\begin{array}{c}\text { Weight after feed } \\
\text { deprivation (g) }\end{array}$ & $\begin{array}{c}\text { Final weight } \\
\text { (g) }\end{array}$ \\
\hline 0 & $7.04 \pm 0.01$ & $9.53 \pm 1.15^{\mathrm{a}}$ & $26.11 \pm 1.48^{\mathrm{a}}$ \\
1 & $7.02 \pm 0.15$ & $7.28 \pm 0.35^{\mathrm{b}}$ & $26.41 \pm 2.59^{\mathrm{a}}$ \\
2 & $7.05 \pm 0.04$ & $6.18 \pm 0.38^{\mathrm{c}}$ & $20.97 \pm 1.09^{\mathrm{b}}$ \\
\hline
\end{tabular}

Description: Different superscript letters indicate significant difference between treatments

average biomass at the end of the experiment showed that fish biomass of treatment one-week deprivation was higher than those without deprivation. On the other hand, the biomass of the fish that were deprived for two weeks was significantly lower than the other treatments (Table 2).

Based on the results, a complete compensation was found after one-week feed deprivation. Compensatory growth may be an internal adjustment mechanism for animals to adapt to often dramatically varied environments. The animals that withstand a period of nutrition restriction could return to a normal growth trajectory (Ali et al., 2001). No significant difference in body weights and biomass was found bet-ween one-week deprived group and the group without feed deprivation. Similar effects of feed deprivation on growth and body composition were also reported in previous studies (Oh et al., 2007; Morshedi et al., 2013; Yengkokpam et al., 2014; Pang et al., 2016). The present study showed that tilapia were unable to compensate weight losses during two weeks of feed deprivation period, which resulted in significantly lower body weight and biomass compared to the other groups at the end of the experiment. In line with Dharma \& Suhenda (1986), several factors in the food transformation affected the growth performance such as the amount of feed consumed, digestibility, digestion rate, feeding frequency, food absorption, as well as feed efficiency and feed conversion. One week feed deprivation on tilapia caused a faster response to food transformation into body tissue, which related to its growth.

Compensatory growth occurred as a response to hyperphagia (Ali \& Wootton, 2003), which contributed to energy restoration from the starvation period and catch up the weight loss by greater growth if fish had eaten without restriction. The magnitude of compensatory growth was depending on how severe fish experienced the undernutrition conditions (Fu et al., 1998). Hyperphagia in fish is known as a response to a reduction in feeding frequency accompanied by an increase in gastric capacity which results in body mass increase (Fabry, 1969; Jobling, 1982). In the present study, hyperphagia appeared on the deprived fish groups. Results of this study showed that one-week deprived fish consumed feed above normal during refeeding period and grew faster $(0.46$ $\pm 0,06 \mathrm{~g} /$ day) than control $(0.39 \pm 0.04 \mathrm{~g} /$ day). Meanwhile, two-week deprived fish grew slower than the control during refeeding period $(0.35 \pm 0.03 \mathrm{~g} / \mathrm{day})$. It means that duration and frequency of feeding during refeeding was important for compensatory growth.

The present study showed lower mortality rate $(<9 \%$ in all treatments. The aggressive behavior of fish which resulted in injuries was the major cause of mortality. Meanwhile, specific growth rates accord-

Table 2. Biomass gain comparison of tilapia based on duration of feed deprivation

\begin{tabular}{cccc}
\hline $\begin{array}{c}\text { Duration of feed } \\
\text { deprivation (week) }\end{array}$ & $\begin{array}{c}\text { Initial biomass } \\
\mathbf{( g )}\end{array}$ & $\begin{array}{c}\text { Total biomass after } \\
\text { feed deprivation }(\mathbf{g})\end{array}$ & $\begin{array}{c}\text { Final biomass } \\
\mathbf{( g )}\end{array}$ \\
\hline 0 & $140.79 \pm 0.27$ & $190.68 \pm 23.01^{\mathrm{a}}$ & $486.79 \pm 13.59^{\mathrm{a}}$ \\
1 & $140.37 \pm 3.03$ & $145.59 \pm 6.94^{\mathrm{b}}$ & $491.97 \pm 32.28^{\mathrm{a}}$ \\
2 & $141.07 \pm 0.72$ & $123.69 \pm 7.54^{\mathrm{c}}$ & $383.96 \pm 8.23^{\mathrm{b}}$ \\
\hline
\end{tabular}

Description: Different superscript letters indicate significant difference between treatments 
ing to wet weight, protein, and lipid were not significantly different between one-week deprivation treatment and those treatments without deprivation $(P>0.05)$. However, the specific growth rates of both groups were significantly higher than that of the two weeks deprivation group $(\mathrm{P}<0.05)$ (Table 3$)$.

Improvement in the specific growth rate of wet weight, protein, and lipid in tilapia deprived for one week indicated that tilapia have the ability to compensate for weight losses up to one week of feed deprivation. This result was similar to the results of Cho (2005) who found specific growth rate improvement during compensatory growth observation of juvenile flounder (Paralichthys olivaceus). However, Wang et al. (2009) reported that cyclical feed deprivation and refeeding failed to enhance compensatory growth in Nile tilapia Oreochromis niloticus L.

At the end of the experiment, the highest moisture and ash concentration was found in fish deprived for two weeks. However, statistical analysis indicated that the difference was not significantly different among the treatments. The moisture concentration was only found in the one week deprived group treatment (Table 4). Meanwhile, the highest protein and lipid concentrations were found in fish without deprivation. Protein and lipid concentrations of the deprived groups were significantly lower than those without deprivation $(\mathrm{P}<0.05)$. On the other hand, higher concentrations of ash were found at the deprived groups compared with the group without feed deprivation.

Lower concentrations of lipid and protein in the fish body were found in feed-deprived groups. According to Fu et al., (1998) the variation of lipid and protein concentrations highly dependent on fish species and size, water temperature, and duration of feed deprivation. The depletion of protein and lipid concentrations due to feeding deprivation was also reported by Wang et al. (2000) and Wang et al. (2009). This study indicates that the fish suffered from feed deprivation exhibited lower body protein and lipid concentration than the control group at the end of the experiment. Fish used their protein and lipid for metabolic energy during feed deprivation period (Navarro \& Gutierrez, 1995; Fu et al., 1998).

\section{CONCLUSION}

A complete growth compensation regarding feeding deprivation of Oreochromis niloticus BEST tilapia strain only occurred no longer than one week deprivation period. A much longer period of feed deprivation would result in a lower growth performance. The results of the present study could be applied as a basic information for future research to determine the effective and efficient feeding strategies for culturing BEST tilapia strain.

Table 3. Specific growth rates of wet weight, protein, and lipid comparison of tilapia based on duration of feed deprivation

\begin{tabular}{ccccc}
\hline $\begin{array}{c}\text { Duration of feed } \\
\text { deprivation (week) }\end{array}$ & $\begin{array}{c}\text { Specific growth rate of } \\
\text { wet weight }(\%)\end{array}$ & $\begin{array}{c}\text { Specific growth rate of } \\
\text { protein }(\%)\end{array}$ & $\begin{array}{c}\text { Specific growth rate of } \\
\text { lipid }(\%)\end{array}$ & $\begin{array}{c}\text { Survival rate } \\
(\%)\end{array}$ \\
\hline 0 & $2.34 \pm 0.10^{\mathrm{a}}$ & $1.75 \pm 0.07^{\mathrm{a}}$ & $2.12 \pm 0.07^{\mathrm{a}}$ & $93.33 \pm 2.89^{\mathrm{a}}$ \\
1 & $2.36 \pm 0.15^{\mathrm{a}}$ & $1.74 \pm 0.11^{\mathrm{a}}$ & $2.01 \pm 0.11^{\mathrm{a}}$ & $93.33 \pm 2.89^{\mathrm{a}}$ \\
2 & $1.94 \pm 0.09^{\mathrm{b}}$ & $1.44 \pm 0.09^{\mathrm{b}}$ & $1.74 \pm 0.07^{\mathrm{b}}$ & $91.67 \pm 2.89^{\mathrm{a}}$ \\
\hline
\end{tabular}

Description: Different superscript letters indicate significant difference between treatments

Table 4. Body composition of tilapia before and after feed deprivation treatments

\begin{tabular}{ccccc}
\hline $\begin{array}{c}\text { Duration of feed } \\
\text { deprivation (week) }\end{array}$ & $\begin{array}{c}\text { Moisture } \\
\text { (\%) }\end{array}$ & $\begin{array}{c}\text { Protein } \\
\text { (\%) }\end{array}$ & $\begin{array}{c}\text { Lipid } \\
\text { (\%) }\end{array}$ & $\begin{array}{c}\text { Ash } \\
\text { (\%) }\end{array}$ \\
\hline Initial & $77.10 \pm 0.27$ & $51.41 \pm 0.06$ & $17.71 \pm 0.06$ & $19.35 \pm 0.08$ \\
Final : 0 & $74.59 \pm 0.38^{\mathrm{a}}$ & $52.41 \pm 0.08^{\mathrm{a}}$ & $23.89 \pm 0.13^{\mathrm{a}}$ & $16.08 \pm 0.10^{\mathrm{b}}$ \\
Final : 1 & $73.50 \pm 0.44^{\mathrm{b}}$ & $51.46 \pm 0.01^{\mathrm{b}}$ & $21.68 \pm 0.12^{\mathrm{c}}$ & $17.40 \pm 0.06^{\mathrm{a}}$ \\
Final : 2 & $75.04 \pm 0.31^{\mathrm{a}}$ & $51.30 \pm 1.07^{\mathrm{b}}$ & $22.30 \pm 0.07^{\mathrm{b}}$ & $17.51 \pm 0.04^{\mathrm{a}}$ \\
\hline
\end{tabular}

Description: Different superscript letters indicate significant difference between treatments 


\section{ACKNOWLEDGEMENT}

We thank Bambang Priadi, Ati Puspitasari, Usman, and Khazaidan for their involvement during the research preparation and experiment activities. We also thank the Institute for Freshwater Aquaculture Research and Fisheries Extension, Bogor for supporting this research.

\section{REFERENCES}

Ali, M., Cui, Y., Zhu, X., \& Wootton, R.J. (2001). Dynamics of appetite in three fish species (Gasterosteus aculeatus, Phoxinus phoxinusc and Carassius auratus gibelio) after feed deprivation. Aquaculture Research, 32, 443-450.

Ali, M., \& Wootton, R.J. (2003). Compensatory growth in fishes: a response to growth depression. Fish and Fisheries, 4, 147-190.

Cui, Y., Hung, S.S.O., Deng, D.F., \& Yang, Y. (1997). Growth of juvenile white sturgeon as affected by feeding regime. Progressive Fish-Culturist, 59, 3135.

Cho, S.H. (2005). Compensatory growth of juvenile flounder Paralichthys olivaceus $L$. and changes in biochemical composition and body condition indices during starvation and after refeeding in winter season. Journal of The World Aquaculture Society, 36(4), 508-514.

Cho, S.H., Lee, S.M., Park, B.H., Ji, S.C., Lee, J.H., Bae, J.H., \& Oh, S.Ys. (2006). Compensatory growth of juvenile olive flounder, Paralichthys olivaceus L., and changes in proximate composition and body condition indexes during fasting and after refeeding in summer season. Journal of The World Aquaculture Society, 37(2), 168-174.

Dharma, L. \& Suhenda, N. (1986). Pengaruh pemberian pakan dengan tangan dan alat self feeder terhadap pertumbuhan dan produksi ikan mas di kolam air deras. Bulletin Penelitian Perikanan Darat, 5(1), 7984.

Fabry, P. (1969). Feedingc patterns and nutritional adaptations. London: Butterworths.

Fu, C., Cui, Y., Hung, S.S.O., \& Zhu, Z. (1998). Growth and feed utilization by $F 4$ human growth hormone transgenic carp fed diets with different protein levels. Journal of Fish Biology, 53, 115-129.

Gustiano, R. (2009). BEST tilapia: New flagship, quality expectancy. TROBOS Magazine October 2009 Edition, p. 116-117. (in Indonesian)

Hayward, R.S., Noltie, D.B., \& Wang, N. (1997). Use of compensatory growth to double hybrid sunfish growth rates. Transactions of the American Fisheries Society, 126, 316-322.
Hitchcock, M.J. (2013). Side effects of feed restriction and compensatory growth in fish. Thesis. University of Otago. New Zealand, $182 \mathrm{pp}$.

Jiwyam, W. (2010). Growth and compensatory growth of juvenile Pangasius bocourti Sauvage, 1880 relative to ration. Aquaculture, 306, 393-397.

Jobling, M. (1982). Some observations on the effects of feeding frequency on the food intake and growth of plaice, Pleuronectes platessa L. Journal of Fish Biology, 20, 431-444.

Jobling, M. (2010). Are compensatory growth and catch-up growth two sides of the same coin?. Aquaculture International, 18, 501-510.

Mohanta, K.N., Rath, S.C., Nayak, K.C., Pradhan, C., Mohanty, T.K., \& Giri, S.S. (2016). Effect of restricted $x$ feeding and refeeding on compensatory growth, nutrient utilization and gain, production performance and whole body composition of carp cultured in earthen pond. Aquaculture Nutrition, $10 \mathrm{pp}$.

Morshedi, V., Kochanian, P., Bahmani, M., YazdaniSadati, M.A., Pourali, H.R., Ashouri, G., PashaZanoosi, H., \& Azodi, M. (2013). Compensatory growth in sub-yearling Siberian sturgeon, Acipenser baerii Brandt, 1869: Effects of starvation and refeeding on growth, feed utilization and body composition. Journal of Applied Ichthyology, 29, 978983.

Navarro, I. \& Gutierrez, J. (1995). Fasting and starvation. In Biochemistry and Molecular Biology of Fishes. Hochachka, P.W. \& Mommsen, T.P. (Eds.), p. 393-434. Amsterdam: Elsevier.

Oh, S.Y., Noh, C.H., \& Cho, S.H. (2007). Effect of restricted feeding regimes on compensatory growth and body composition of Red Sea Bream, Pagrus major. Journal of TheWorld Aquaculture Society, 38(3), 443-449.

Pang, X., Fu, S.J., Li, X.M., \& Zhang, Y.G. (2016). The effects of starvation and re-feeding on growth and swimming performance of juvenile black carp (Mylopharyngodon piceus). Fish Physiology and Biochemstry, $10 \mathrm{pp}$.

Peres, H., Santos, S., \& Oliva-Teles, A. (2011). Lack of compensatory growth response in gilthead seabream (Sparus aurata) juveniles following starvation and subsequent refeeding. Aquaculture, 318, 384-388.

Ribeiro, F.F. \& Tsuzuki, M.Y. (2010). Compensatory growth responses in juvenile fat snook, Centropomus parallelus Poey, following food deprivation. Aquaculture Research, 41, 226-233.

Stefansson, S.O., Imsland, A.K., \& Handeland, S.O. (2009). Food-deprivation, compensatory growth 
and hydro-mineral balance in Atlantic salmon (Salmo salar) post-smolts in sea water. Aquaculture, 290, 243-249.

Urbinati, E.C., Sarmiento, S.J., \& Takahashi, L.S. (2014). Short-term cycles of feed deprivation and refeeding promote full compensatory growth in the Amazon fish matrinxã (Brycon amazonicus). Aquaculture, 433, 430-433.

Wang, Y., Cui, Y., Yang, Y., \& Cai, F. (2000). Compensatory growth in hybrid tilapia, Oreochromis mossambicus $\times 0$. niloticus reared in seawater. Aquaculture, 189, 101-108.

Wang, Y., Cui, Y., Yang, Y., \& Cai, F. (2005). Partial compensatory growth in hybrid tilapia Oreochromis mossambicus $\times 0$. niloticus following food deprivation . Journal of Applied Ichthyology, 21, 389-393.
Wang, Y., Li, C., Qin, J.G., \& Han, H. (2009). Cyclical feed deprivation and refeeding fails to enhance compensatory growth in nile tilapia, Oreochromis niloticus L. Aquaculture Research, 40, 204-210.

Xie, S., Zhu, X., Cui, Y., Wootton, R.J., Lei, W., \& Yang, Y. (2001). Compensatory growth in gibel carp following feed deprivation: temporal patterns in growth, nutrient deposition, feed intake and body composition. Journal of Fish Biology, 58, 999-1009.

Yengkokpam, S., Sahu, N.P., Pal, A.K., Debnath, D., Kumar, S., \& Jain, K.K. (2014). Compensatory growth, feed intake and body composition of Labeo rohita fingerlings following feed deprivation. Aquaculture Nutrition, 20, 101-108. 